\title{
THE SYSTEM OF GREEN CERTIFICATES - PROMOTER OF ENERGY FROM RENEWABLE RESOURCES
}

\author{
Leontina Păvăloaial \\ Iuliana Georgescu ${ }^{2}$
}

\begin{abstract}
The traditional economic development aims at customer satisfaction and profits maximization, but overused the natural resources. Therefore, it becomes a necessity to take into account the social and environmental aspects. In order to ensure sustainable development, it have been adopted numerous rules and regulations which set objectives and targets aiming to reduce emissions and contributing to a responsible behavior. One of the objectives set at EU level is to ensure that sustainable development is the use of renewable resources in the production of electricity. In order to encourage the use of renewable energy sources for energy production it applied a system of promotion throughout green certificates, which aims, among other goals, to reduce imports of primary energy resources, stimulate the local and regional sustainable development, create employment throughout new jobs, reduce the environmental pollution by minimizing emissions. In this paper we intend to analyze the tools used in Romania for the purpose of promoting the production of energy from renewable sources, the green certificates market, the share of renewable energy in gross inland consumption, the fulfillment degree of the target and their reflection in the annual financial statements of energy production companies listed on the Bucharest Stock Exchange.
\end{abstract}

Keywords: green certificate, renewable energy sources, sustainable development

JEL Codes: Q56

\section{Introduction}

Promoting the energy renewable sources for the electric power production has been encouraged within the EU through the 2001/77/CE and 2003/30/CE directives which have been modified through the 2009/28/CE directive. These regulations settle the objectives to be fulfilled until 2020 within the EU and the Member States. Thus, 20\% of the community energy consumption has to be produced from renewable sources (national percentage of 24\%), and the percentage of biofuels in the gas and diesel consumption in the transportation system has to reach $10 \%$. Romania has transposed into the national legislation the purviews of the European directives and aims that by the end of 2015, the percentage of renewable sources energy is to reach $35 \%$ of the final raw electric power consumption and 38\% by 2020 (Law 139/2010).

\section{The energy from renewable source at EU level}

By analyzing the EU case, it has been noticed that more supporting instruments are used for the promotion of the RES production (table no. 1).

\footnotetext{
1 "Alexandru Ioan Cuza" University of Iasi, Romania, e-mail: betianu@uaic.ro

2 "Alexandru Ioan Cuza" University of Iasi, Romania, e-mail: iuliag@uaic.ro
} 
Table no. 1

RES instruments in EU 27

\begin{tabular}{|c|c|c|c|c|c|c|}
\hline & $\begin{array}{c}\text { Feed-in } \\
\text { tariff }\end{array}$ & Premium & $\begin{array}{c}\text { Quota } \\
\text { obligation }\end{array}$ & $\begin{array}{c}\text { Investment } \\
\text { grants }\end{array}$ & $\begin{array}{c}\text { Tax } \\
\text { exemptions }\end{array}$ & $\begin{array}{c}\text { Fiscal } \\
\text { incentives }\end{array}$ \\
\hline Austria & $\mathrm{x}$ & & & & & \\
\hline Belgium & $\mathrm{x}$ & & $\mathrm{x}$ & $\mathrm{x}$ & $\mathrm{X}$ & \\
\hline Bulgaria & $\mathrm{x}$ & & & & & $\mathrm{x}$ \\
\hline Cyprus & $\mathrm{x}$ & & & $X$ & & \\
\hline $\begin{array}{l}\text { Czech } \\
\text { Republic }\end{array}$ & $\mathrm{x}$ & $\mathrm{x}$ & & $\mathrm{x}$ & & \\
\hline Denmark & & $\mathrm{x}$ & & & & \\
\hline Estonia & $\mathrm{x}$ & $\mathrm{x}$ & & & & $\mathrm{x}$ \\
\hline Finland & & & & $\mathrm{x}$ & $\mathrm{x}$ & \\
\hline France & $\mathrm{x}$ & & & & & \\
\hline Germany & $\mathrm{x}$ & & & & & $\mathrm{x}$ \\
\hline Greece & $\mathrm{x}$ & & & $X$ & $X$ & \\
\hline Hungary & $\mathrm{x}$ & & & $\mathrm{x}$ & & \\
\hline Ireland & $\mathrm{x}$ & & & & & \\
\hline Italy & $\mathrm{x}$ & & $\mathrm{x}$ & & & \\
\hline Latvia & $\mathrm{x}$ & & & $\mathrm{x}$ & $\mathrm{x}$ & \\
\hline Lithuania & $\mathrm{x}$ & & & $\mathrm{x}$ & & \\
\hline Luxembourg & $\mathrm{x}$ & & & $\mathrm{x}$ & & \\
\hline Malta & $\mathrm{x}$ & & & $\mathrm{x}$ & & $\mathrm{x}$ \\
\hline Netherlands & & $\mathrm{x}$ & & & $\mathrm{x}$ & $\mathrm{x}$ \\
\hline Poland & & & $\mathrm{x}$ & & $\mathrm{x}$ & $\mathrm{x}$ \\
\hline Portugal & $\mathrm{x}$ & & & & & \\
\hline Romania & & & $\mathrm{x}$ & & & \\
\hline Slovakia & $\mathrm{x}$ & & & & $\mathrm{x}$ & \\
\hline Slovenia & $\mathrm{x}$ & $\mathrm{x}$ & & & & $\mathrm{x}$ \\
\hline Spain & $\mathrm{x}$ & $\mathrm{x}$ & & & $\mathrm{x}$ & \\
\hline Sweden & & & $\mathrm{x}$ & & $\mathrm{x}$ & \\
\hline $\begin{array}{l}\text { United } \\
\text { Kingdom }\end{array}$ & $\mathrm{x}$ & & $\mathrm{x}$ & & $\mathrm{x}$ & \\
\hline
\end{tabular}

Source: Ecofys, 2011

The most frequently used RES promoting schemes are (Ford et al., 2007):

- The fixed prices system (feed-in tariff) consisting of the producers', providers' or consumers' acquisition of renewable sources energy at a fixed price; the price is set depending on the renewable source used for the energy production;

- The annual mandatory quota, combined with the combined with the green certificates system. In the case of this system, the Governments establish the renewable sources energy quota that is to be purchased by producers, providers or consumers, and the acquisition price is set on the market.

More studies and analyses of the RES have been carried on within the EU. Amundsen and Nese (2009) analized the effects on adopting tradable green certificate over production of energy from renewable sources in the Northen countries, also taking into account the certificate system of Green Emission Systems (GES). The conclusion they was that TGC is an unprecised tool, and the 
combination with GES may lead to results that are opposite to the aimed results. One of the identified problems is price volatility of green certificate, which is generated by the dependece of climate conditions (wind, sun, rainfall), implying a variable rate of return to investors. Another identified problem is the large share of a producer of green energy that can have on the market, highly connected to Mwh consumption, as the producer can significantly reduce consumption and thereby increase the price to the end user. The authors recommend caution in adopting this system, especially if applied together with the GES.

Another study was conducted by Aune et al., (2012), who developed a digital system that has been shown that the application of the trading systems of TGC can reduce the total cost of fulfilling the EU renewable target by $70 \%$. However, the design of markets for green certificates can have a significant impact on the distribution of costs between countries.

Del Rio (2005) analyzed the advantages and disadvantages resulting from the harmonization of RES support schemes in Europe, and its main applications is that, although for the RES Directive objectives is relevant the cost-effectiveness ratio, at national level are also important other objectives, they should not be sacrificed in the name of cost-effectiveness. Another issue highlighted was that immature technologies are unlikely to enter the market, but may have hidden potential that could generate important social benefits.

Continuing the current policies compared to EU harmonization combined with a TGC system has a cost to the consumer and/or contributor and should be taken into account in decision making. Harmonization and the development of a single EU energy market could lead to significant cost savings (Aune et al., 2012) but should be considered the difficulties that may arise in this regard, such as the example of Belgium where harmonization of the four TGC systems is a major challenge (Verhaegen et al., 2009). Also should be taken into account the different national objectives, because under these conditions a common market does not ensure energy efficiency (Aune et al., 2012). The main benefits expected TGC are obtaining an optimal cost-effectiveness ratio, providing a stable development in relation to the set objectives, while ensuring technological development and cost reduction throughout the „double”competition within the two markets: for electricity and green certificates (Bergek and Jacobsson, 2010). Among the disadvantages, shoudl be mentioned the price volatility caused by weather conditions and the need to avoid pricing restrictions due to a limited number of manufacturers.

The analysis conducted EC in 2011 concluded that there progress has been made, but there is still much to be done.Most of the member states have focused on the national resources in order to reach the objectives by their own. Thus, the Commission has estimated that up to 10 billion euro could have been saved each year if the member states had traded the energy on a single European market, rather than on the national markets. The transition to market integration is too slow, too fragmented and needs consolidation (SEC, 2011, 131).

Fig. no. 1 shows the RES percentage within the EU between 2004 and 2011. 


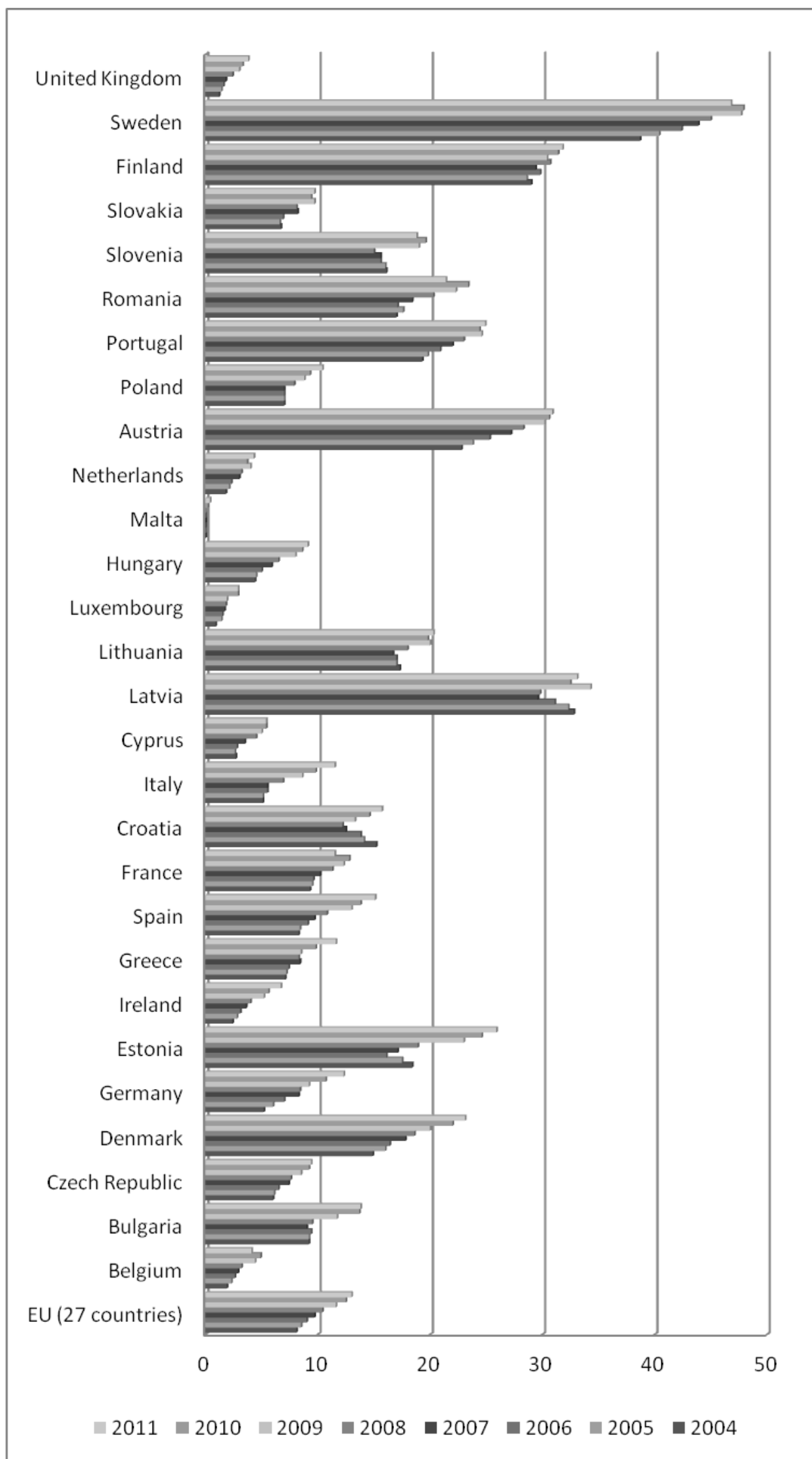

Figure no. 1 - RES percentage within the EU between 2004 and 2011 (\%) Source: Eurostat, 2011 
In the EC report from 2012 it is stated that still require a serious debate at EU level on the proper mechanisms and tools to promote a coordinated RES. Market-based regulatory tools are required in order to achieve joint strategy to ensure an efficient transition and viable from a social point of view (COM(2012) 271 final).

\section{RES in Romania}

Next we consider the system to promote the production of energy from renewable sources at national level and information published in the annual reports of companies listed on the BSE in the 1 st category and the main actors from the CV market.

\section{The application of the CV at national level}

At a national level, the system of the mandatory quota combined with the green certificates (GC) was adopted and in applies to the electric power produced from the wind, solar, geothermal energy, biomass, waste fermentation gas and muds from the purge installations of used water, as well as the electric power produced in the hydro-electric power plants with an installed power of up to $10 \mathrm{Mwh}$.

There were changes in the legislation in 2013, thus reducing the number of given certificates, and some of them were delayed from trading. These changes lead to great debates, and there is no agreement from the EU up till now. The recovery of the delayed green certificates will start from April $1^{\text {st }} 2017$ for the new hydro-electric power plants up to $10 \mathrm{MW}$ and the solar energy power plants, and from January $1^{\text {st }} 2018$ for the wind power plants, spread over to maximum December $31^{\text {st }}$ 2020. Table no. 2 shows the number of certificates given to each Mwh that was produced from renewable sources and delivered to the network.

Table no. 2

The number of certificates given for each Mwh produced from renewable sources

\begin{tabular}{|l|l|l|}
\hline $\begin{array}{l}\text { hydro with an installed } \\
\text { power of maximum 10 } \\
\text { MW }\end{array}$ & $\begin{array}{l}\text { 3 GC for the new ones in function } \\
\text { starting from January 1st 2004, } \\
\text { 2 GC for the retechnologized ones } \\
\text { since January 1st 2004, } \\
0,5 \text { for the unreconditioned ones }\end{array}$ & \multicolumn{1}{c|}{ GEO no. 57/2013 } \\
\hline wind & $\begin{array}{l}\text { 2 GC until 2017 } \\
1 \text { GC from 2018 }\end{array}$ & 1 GC new ones \\
\hline $\begin{array}{l}\text { geothermal, biomass, } \\
\text { fermentation gas }\end{array}$ & $3 \mathrm{GC}$ & \\
\hline solar & $6 \mathrm{GC}$ & $2 \mathrm{GC}$ \\
\hline
\end{tabular}

Source: Law no. 220/2008, GEO no. 57/2013

The National Regulatory Authority for Energy (ANRE) sets the annual mandatory quota for the purchase of a GC of the previous year, based on the produced electrical energy volumes from renewable sources and on the final electric energy consumption of the former year. The RES producers can sell the green certificates they received for the network delivered energy. These are capitalized on the market and do not depend on the trading of the corresponding electrical energy; thus, the certificates are traded:

- On a bilateral market, where producers and providers make agreements and where the price of the green certificates is established through free negotiation between the two contractors; and/or

- On a centralized market for green certificates, organized and administrated by the electrical 
energy market operator (EEMO), in his position of green certificates market operator.

The value of the green certificates is separately invoiced from the tariffs/prices of the electrical energy, being separately emphasized on the electrical energy bill. The value is established by weighting the annual mandatory quota for the certificate acquisition and the billed electrical energy and with the medium weighted price of the green certificates traded on the centralized market.

The GC market is nationally operational since 2005, the first green certificates being issued, which were traded on the centralized market in November (7,608 GC). 5,547,302 GC were issued in 2012 , of which $79.8 \%$ for the wind power plants, $13.5 \%$ for the hydro-electric power plants, $5.9 \%$ for the plants using biomass and $0.8 \%$ for the photovoltaic power stations. Fig. no. 2 shows the evolution of the traded certificates number.

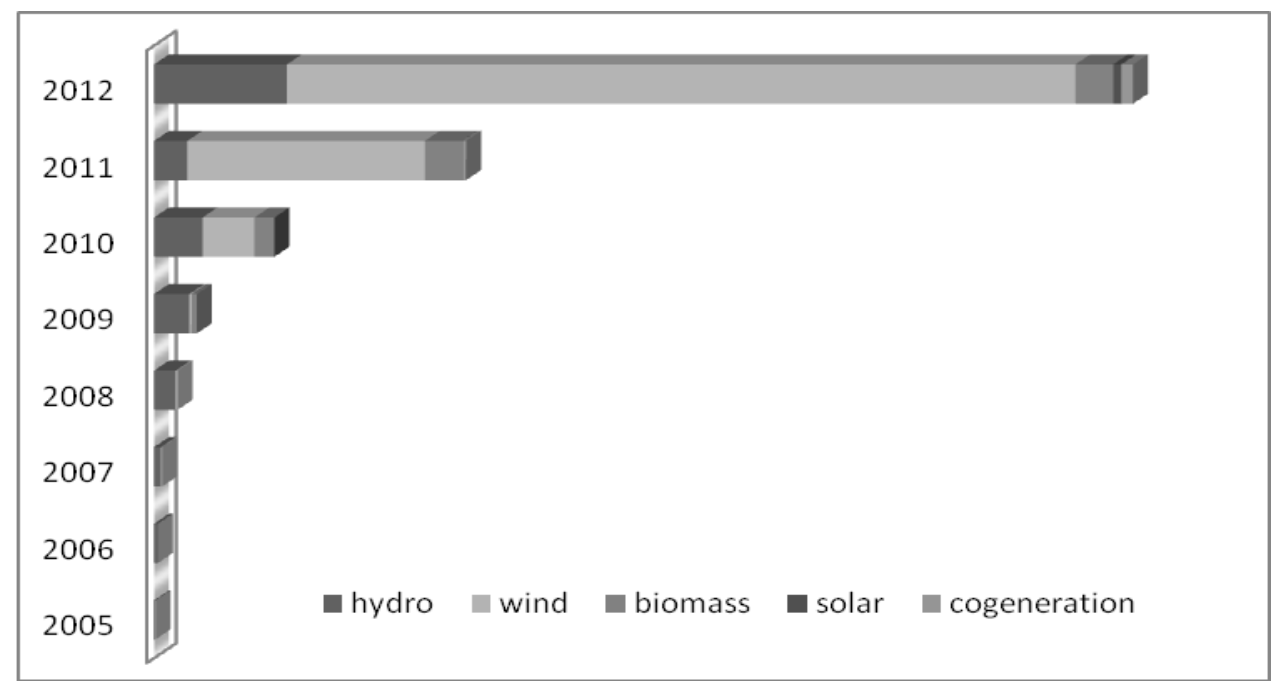

Figure no. 2 - Green certificates issued between 2005 and 2012 Source: ANRE, 2013

As for the structure of the electrical energy delivered in the network by producers in 2012: $37.6 \%$ solid fuel, $22.2 \%$ hydro-electrical energy, $19.6 \%$ nuclear energy, $14.3 \%$ gas fuel, $5.3 \%$ wind energy, $0.6 \%$ liquid fuel and $0,4 \%$ other renewable sources.

The structure of the offered and sold GC on the two markets in 2012 is (ANRE, 2013):

- $36.67 \%$ on the centralized market of green certificates;

- $62.2 \%$ on the bilateral contracts market (producers and providers);

- $1.13 \%$ transferred from the producer account to the provider account, for the same economic operator that has the quality of both producer and provider.

The value of the green certificates is established on both markets and is limited by law to 29$58 € / \mathrm{GC}$, indexed with the euro zone annual inflation rate. This limitation is imposed in order to protect producers and consumers. Not fulfilling the mandatory quota leads to penalties payment (114.77 €/GC in 2012), and the guilty provider has its functioning license suspended until the complete payment of the equivalent values of the unpurchased green certificates. The evolution of the selling price of the electrical energy from renewable sources is displayed in table no. 3.

The evolution of the RES selling price between 2005 and 2010 (euro)

\begin{tabular}{|c|c|c|c|c|c|c|c|c|}
\hline & 2005 & 2006 & 2007 & 2008 & 2009 & 2010 & 2011 & 2012 \\
\hline GC & 38 & 42 & 42 & 45.9 & 55 & 55 & 56.156 & 56.08 \\
\hline
\end{tabular}




\begin{tabular}{|l|r|r|r|r|c|c|c|c|}
\hline RES & 36.42 & 37.45 & 39.55 & 35.8 & 31.15 & 31.35 & 37.133 & 44.4 \\
\hline Penalties & 6.2 & 9.38 & 8.65 & - & - & - & - & - \\
\hline Total & 80.62 & 88.83 & 90.2 & 81.7 & 86.15 & 86.35 & 93.288 & 100.48 \\
\hline
\end{tabular}

Source: ANRE, 2013

Not fulfilling the mandatory quota in 2012 lead to the collection of 19,514 mil. lei as a revenue for the Environment Fond, used at financing the production of energy from renewable sources by private individuals.

ANRE yearly determines the fulfillment degree of the mandatory quota for each electrical energy provider. The electrical energy producers coming from renewable sources could export green certificates in order to trade them on the European green certificates market according to the ANRE regulations and only if the national objectives are fulfilled. Until the national objectives are fulfilled, the green certificates will be traded on the internal market only.

The 2012 report published by the ANRE specifies that a provider was obliged to buy a GC for each 8 Mwh of provided energy (Fig. no. 3).

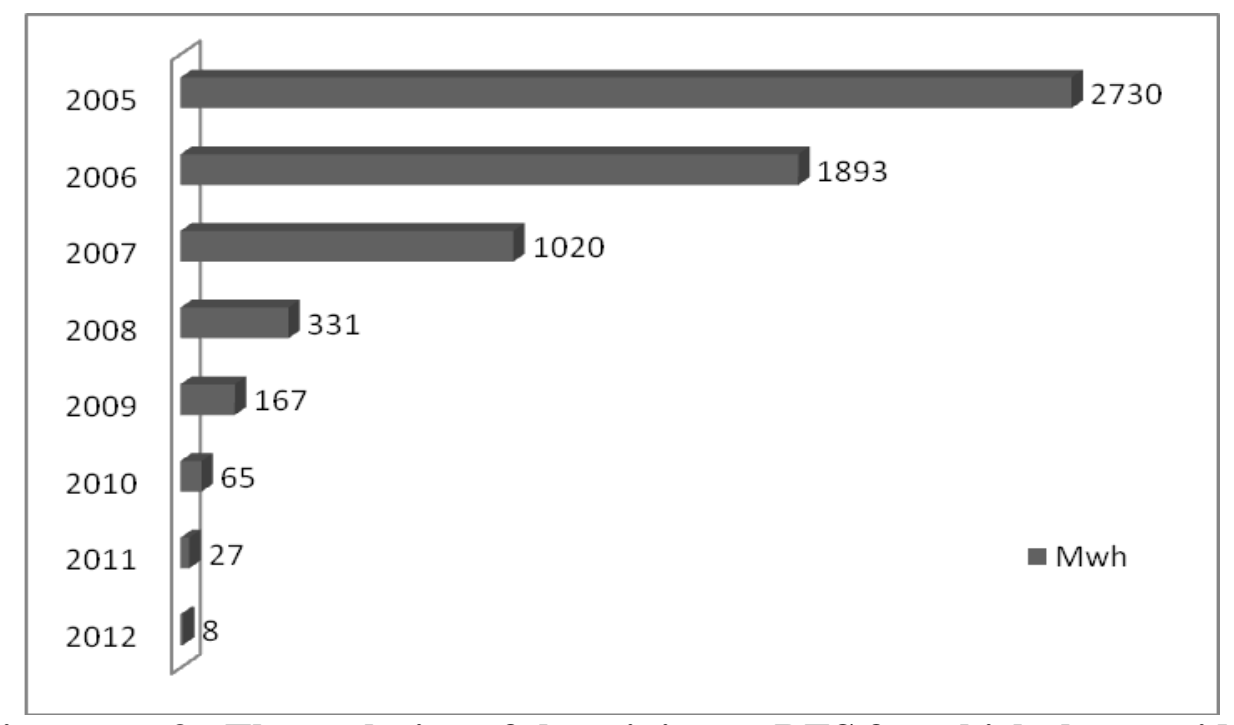

Figure no. 3 - The evolution of the minimum RES for which the provider is obliged to purchase a GC

Source: ANRE, 2013

Between 2005 and 2012, Romania did not manage to reach its set objectives (Table no. 4). Nationally, the RES in 2012 reached 14,977 Twh, which lead to a $33.86 \%$ percentage of the RES in the whole final raw electrical energy consumption (reaching almost the $34 \%$ target).

Table no. 4

The percentage of the RES in the raw internal consumption (\%) and objective fulfillment

\begin{tabular}{|l|c|c|c|c|c|c|c|c|}
\hline & $\mathbf{2 0 0 5}$ & $\mathbf{2 0 0 6}$ & $\mathbf{2 0 0 7}$ & $\mathbf{2 0 0 8}$ & $\mathbf{2 0 0 9}$ & $\mathbf{2 0 1 0}$ & $\mathbf{2 0 1 1}$ & $\mathbf{2 0 1 2}$ \\
\hline $\begin{array}{l}\text { The RES percentage in } \\
\text { the raw internal } \\
\text { consumption (\%) }\end{array}$ & 35.8 & 31.6 & 27.3 & 28.3 & 28.2 & 30.82 & 31.72 & 33.86 \\
\hline $\begin{array}{l}\text { The national objective } \\
\text { fulfillment degree (\%) }\end{array}$ & 86.6 & 84.8 & 85.5 & 86.2 & 85.5 & 93.39 & 94.97 & 96.74 \\
\hline
\end{tabular}

Source: ANRE, 2013 
By analyzing the data provided by ANRE, it has been noticed that the RES production hasn't registered a constant evolution. When the GC trading began in 2005, the objective fulfillment degree reached $86.6 \%$, with an oscillating evolution for the next 4 years, with the lowest value in 2006, and, starting from 2010, due to the putting into service of the wind farm, there has been a growth of the RES production. Starting from 2011, Romania made its presence felt on the unconventional energy market by entering the European top ten wind energy ranking due to an installed power of $520 \mathrm{Mwh}$ (GWCE, 2011).

\section{Information related to $C V$ within the annual reports}

Information about green certificates published in the annual reports of the $\mathrm{I}^{\text {st }}$ category BSE listed companies has also been taken into account. Sadly, a small number of companies issue such information. Nuclearelectrica reports only in Note no 15th information related to the incomes from sale of CVs of 7 mil. lei in 2012 and 2 mil. lei in 2011, without stating the related expenses or the number of owned certificates.

Other companies do not publish quantitative info, they only offer certain explanations regarding green certificates. Thus, Alro registered in 2012 a significant cost growth, assuming that "the renewable energy and cogeneration 18 euro/MWh taxes only represent the equivalent of a approximate 260 euro/ton impact". In the ANRE 2012 report, it is specified that the percentage of the green certificate purchasing of ALRO has varied between $22.3 \%$ and $6.62 \%$, with a $7.93 \%$ market share.

Taking this case into account, we have consulted the financial situations of the RES producers. Hence, the CEZ group has created a 25,924 thousands lei provision at the end of 2012 (10,513 thousand lei in 2011) for 104,552 green certificates (43,616 GC in 2011), which were to be purchased in order to reach the annual quota.

It also has debts resulted from the selling of green certificates for about 42,852 thousand lei and other operating revenues of 231,429 thousand lei (260 thousand in 2011) coming in advance from subsidies as GC received for the renewable sources energy production. In the 2012 financial situations some changes have appeared as the result of adopting the PFMO 118/2012. Thus, unearned revenues growths were registered due to the changes of the accounting policies regarding the registration of green certificates received by the renewable sources energy producing companies.

Enel Group publishes on their own website only information on the amount of energy from renewable sources nationwide. Thus, by the end of 2012 the net installed capacity was about 500 Mwh. Within the Group financial statements are presented the following information on income and expenses recorded at the group level on CV: in 2012 income of 579 mil euro (359 mil. Euro in 2011) and expenses of 488 mil euro (155 mil euro in 2011).

"Electrica Furnizare" only publishes in the annual report only financial information, not quantitative: the income related to CV of $243.3 \mathrm{mil}$ lei and expenses with CV purchase of $301.6 \mathrm{mil}$ lei (a significant difference compared to 39.9 mil lei in 2011), while Petrom present only information about the number of certificates 182,784 in 2012 and 33,050 in 2011.

The lack, at national level, of some regulations to require the publication of in the annual reports of information on green certificates encourages most companies not to publish such information, and those who publish to presented either quantitative (the number of certificates), or income/expenses making comparisons difficult and determining their impact on financial results.

\section{Conclusions}

Choosing the instruments for financing the RES at national and EU level is essential and it depends on the technological development state. More often, initially, in the research phase, are 
supported by public funds, and lately, when they become competitive, no grant is given. Another problem is related to the electrical networks which are not designed for the transportation of large amounts of energy obtained from renewable sources, imposing necessary investments to modernize energy networks whose current situation limits the development of RES. Also, many renewable sources encounter considerable flows (wind parks, photovoltaic systems) which involve the use of non-renewable sources to ensure their functioning.

Nationwide, any revision of financial instruments should be made so that to be avoided uncertainty for investors and to take into account the policies of the other Member States, in order to ensure a consistent approach across the EU. Increasing investments in renewable energy production rise to a number of GC which exceeds the number that should be purchased. This leads to a decrease in the price of certificates or, to an amendment of regulations, and thus reducing the number of GC granted. This is what happened in Romania in 2013 when it was postponed the trading of GCs. This action draws the dissatisfaction of producers who made the investments as they were hoping for more aid (larger number of GC). This is the reason why is necessary to renew the objectives and consequently, to adapt the financing instruments of RES.

Policy makers should consider the main differences and related policies, avoiding the application of the same treatment to all policies.

Also, is necessary to adopt regulations to predict and publish the financial information related to obtaining the RES, such as: the amount of investment made, the subsidies received, income, expenses incurred in order to highlight their effect over the companies' financial results. From the analysis performed at national level it is revealed that the published information are scarce and scattered (annual reports, website, ANRE), CEZ Group being the only one that provide the most complete information.

\section{References}

1. Amundsen E. S., Nese G., 2009. Integration of tradable green certificate markets: What can be expected?, Journal of Policy Modeling, 31, pp. 903-922

2. ANRE, Departamentul reglementare în domeniul eficienţei energetice, Direcţia reglementare în domeniul producerii energiei din surse, regenerabile şi în cogenerare, 2013 - Raport de monitorizare a sistemului de promovare a RES-E in anul 2012, http://www.anre.ro, February 2014

3. Aune F. R., Dalen H. M., Hagem, 2012. Implementing the EU renewable target through green certificate markets, Energy Economics, 34, pp. 992-1000

4. Bergek A., Jacobsson S., 2010. Are tradable green certificates a cost-efficient policy driving technical change or a rent-generating machine? Lessons from Sweden 2003-2008, Energy Policy, 38, pp. 1255-1271

5. Bursa de Valori Bucuresti, on line at: www.bvb.ro, January 2014

6. CEZ Group, www.cez.ro, March 2014

7. $\operatorname{COM(2012)} 271$ final, Comunicarea Comisiei catre Parlamentul European, Consiliu, Comitetul Economic si Social European si Comitetul Regiunilor - Energia din surse regenerabile: o prezenta majora pe piata energetica europeana

8. Directiva 2009/28/CE a Parlamentului European si a Consiliului din 23 aprilie 2009 privind promovarea utilizarii energiei din surse regenerabile, de modificare si ulterior de abrogare a Directivelor 2001/77/CE si 2003/30/CE, JOC 140/16 din 05.06.2009

9. Ecofys, Fraunhofer ISI, TU Vienna EEG, Ernst Young, 2011, Financing Renewable Energy in the European Energy Market, http://ec.europa.eu/energy/renewables/studies/doc/renewables/2011_financing_renewable.p df, March 2014 
10. Eurostat, http://epp.eurostat.ec.europa.eu/tgm/table.do?tab=table\&init=1\&plugin=1\&language $=$ en\&pcode $=$ tsdcc110, March 2014

11. Ford A., Vogstad K., Flynn H., 2007. Simulating Price Patterns for Tradable Green Certificates to promote Electricity Generation from Wind, Energy Policy, 35 (1), pp. 91-111

12. Global Wind Energy Council, 2011, Global Wind Report, Annual market update 2011, http://www.gwec.net/fileadmin/documents/NewsDocuments/Annual_report_2011_lowres.p df, February 2014

13. Legea 220/2008 pentru stabilirea sistemului de promovare a producerii energiei din surse regenerabile de energie, republicata 2010, publicata in Monitorul Oficial, Partea I nr. $577 / 2010$

14. Legea 139/2010 privind modificarea si completarea Legii $n$ r. 220/2008 pentru stabilirea sistemului de promovare a producerii energiei din surse regenerabile de energie, publicată în Monitorul Oficial, Partea I nr. 474/2010

15. OPCOM, www.opcom.ro, January 2014

16. OUG 57/2013 privind modificarea si completarea Legii nr. 220/2008 pentru stabilirea sistemului de promovare a producerii energiei din surse regenerabile de energie, publicată în Monitorul Oficial, Partea I nr. 335/2013

17. del Rio P., 2005. A European-wide harmonised tradable green certificate scheme for renewable electricity: is it really so beneficial?, Energy Policy, 33, pp. 1239-1250

18. SEC (2011) 131 final, Review of European and national financing of renewable energy in accordance with Article 23(7) of Directive 2009/28/EC

19. Verhaegen K., Meeus L., Belman R., 2009. Towards an international tradable green certificate system - The challenging example of Belgiumm, Renewable and Sustainable Energy Reviews, 13, pp. 208-215 